\title{
Potentiation of GluN2C/D NMDA Receptor Subtypes in the Amygdala Facilitates the Retention of Fear and Extinction Learning in Mice
}

\author{
Kevin K Ogden', Alpa Khatri', Stephen F Traynelis*,' and Scott A Heldt*,2,3 \\ 'Department of Pharmacology, Emory University, Atlanta, GA, USA; ${ }^{2}$ Department of Anatomy and Neurobiology; ${ }^{3}$ Neuroscience Institute, \\ University of Tennessee Health Science Center, Memphis, TN, USA
}

\begin{abstract}
NMDA receptors are glutamate receptor ion channels that contribute to synaptic plasticity and are important for many forms of learning and memory. In the amygdala, NMDA receptors are critical for the acquisition, retention, and extinction of classically conditioned fear responses. Although the GluN2B subunit has been implicated in both the acquisition and extinction of conditioned fear, GluN2Cknockout mice show reduced conditioned fear responses. Moreover, D-cycloserine (DCS), which facilitates fear extinction, selectively enhances the activity of GluN2C-containing NMDA receptors. To further define the contribution of GluN2C receptors to fear learning, we infused the GluN2C/GluN2D-selective potentiator CIQ bilaterally into the basolateral amygdala (3, 10, or $30 \mu \mathrm{g} / \mathrm{side})$ following either fear conditioning or fear extinction training. $\mathrm{ClQ}$ both increased the expression of conditioned fear $24 \mathrm{~h}$ later and enhanced the extinction of the previously conditioned fear response. These results support a critical role for GluN2C receptors in the amygdala in the consolidation of learned fear responses and suggest that increased activity of GluN2C receptors may underlie the therapeutic actions of DCS.

Neuropsychopharmacology (2014) 39, 625-637; doi:10.1038/npp.20I3.24I; published online 2 October 2013
\end{abstract}

Keywords: extinction; fear; NMDA; D-cycloserine; GluN2C; GluN2D

\section{INTRODUCTION}

Fear is a normal emotional response that results in a heightened state of arousal in response to an immediate threat or aversive situation. A dysfunctional fear response, however, can lead to anxiety-related disorders in which the heightened state of arousal persists in the absence of an imminent threat. Human anxiety disorders likely result from disruptions in some of the same neuronal circuitry that underlies fear learning in animal models (Cryan and Sweeney, 2011; Graham et al, 2011). However, at present there is an incomplete understanding of the mechanisms or circuitry involved in fear disorders. Thus, elucidation of the circuits, receptors, and mechanisms underlying fear conditioning will help to further characterize the neural basis of fear and anxiety disorders, such as post-traumatic stress disorder and phobias, as well as in the development of new therapeutic strategies.

\footnotetext{
*Correspondence: Professor SF Traynelis, Department of Pharmacology, 5025 Rollins Research Center, Emory University, 1510 Clifton Road, Atlanta 30322, GA, USA, Tel: +404-727-0357, Fax: +404-727-0365, E-mail: strayne@emory.edu or Dr SA Heldt, Neuroscience Institute, University of Tennessee Health Science Center, 855 Monroe Ave, Memphis, Memphis, TN 38I 63, USA, Tel: 90 I-448-5965, Fax: 90।-448-7193, E-mail: sheldt@uthsc.edu

Received I May 2013; revised 15 August 2013; accepted 29 August 2013; accepted article preview online 6 September 2013
}

The acquisition of fear is thought to share some of the same molecular underpinnings as cognitive processes such as learning and memory (for review, see Johansen et al, 2011). Thus, Pavlovian fear conditioning has been shown to strengthen thalamic and cortical inputs to the lateral amygdala (Clem and Huganir, 2010; Hillman et al, 2011; McKernan and Shinnick-Gallagher, 1997; Rogan et al, 1997). Furthermore, fear conditioning attenuates future induction of LTP in the amygdala (Schroeder and Shinnick-Gallagher, 2004, 2005; Tsvetkov et al, 2002), consistent with the idea that fear learning induces LTP-like increases in synaptic strength. In addition, pharmacologic or genetic alterations that impair LTP or LTD in the amygdala also impair fear acquisition or fear extinction (Bauer et al, 2002; Dalton et al, 2012; Li et al, 2013). A reasonable hypothesis has therefore emerged in which psychological disorders that involve altered perception of stimuli as fearful may reflect alterations in the normal learning pathways in regions such as the amygdala. Given the central role of NMDA receptors in mediating plasticity, such as LTP, their involvement has been explored in the context of fear learning.

NMDA receptors are members of the glutamate receptor ion channel family that mediate a slow, $\mathrm{Ca}^{2+}$-permeable component of excitatory synaptic transmission (Traynelis et al, 2010). They are tetrameric ion channels composed of two GluN1 subunits and two GluN2 subunits (Sobolevsky et al, 2009; Ulbrich and Isacoff, 2008). Activation of NMDA 
receptors requires simultaneous binding of agonists to all four subunits, and in the central nervous system (CNS) glycine and D-serine activate the GluN1 subunit, whereas the neurotransmitter glutamate activates the GluN2 subunit. Functional diversity of NMDA receptors arises from eight splice variants of the GluN1 subunit and four gene products for the GluN2 subunit: GluN2A, GluN2B, GluN2C, and GluN2D (Hollmann and Heinemann, 1994). Moreover, expression of the different GluN2 subunits in the CNS is spatially and temporally regulated (Akazawa et al, 1994; Monyer et al, 1994; Standaert et al, 1994), giving rise to NMDA receptors with diverse functional and pharmacological properties in different regions.

Amygdala infusions of the competitive NMDA receptor antagonist AP5 blocked NMDA receptors and prevented the acquisition of learned fear (Miserendino et al, 1990). Subsequently, studies using the GluN2B-selective antagonists ifenprodil or CP-101,606 suggested that GluN2B-containing NMDA receptors may mediate fear memory formation and the underlying synaptic plasticity (Rodrigues et al, 2001; Walker and Davis, 2008). In addition to fear acquisition, NMDA receptors are also critical for the extinction of fear. NMDA receptor antagonists blocked extinction (Baker and Azorlosa, 1996; Falls et al, 1992; Lee and Kim, 1998; Lin et al, 2003; Santini et al, 2001; Suzuki et al, 2004) and D-cycloserine (DCS), an agonist at the GluN1 subunit, enhanced fear extinction (Walker et al, 2002). Interestingly, DCS is a partial agonist at GluN2A, 2B, and 2D receptors but elicits greater currents than saturating concentrations of glycine from GluN2C receptors (Dravid et al, 2010; Sheinin et al, 2001). This finding creates the possibility that DCS increases the retention of fear extinction by at least two mechanisms. First, when endogenous glycine concentrations are submaximal DCS can augment the activity of all NMDA receptors by increasing occupancy of the glycine site. Second, DCS can selectively enhance the response of GluN2C receptors when it replaces glycine as the co-agonist bound to GluN1/GluN2C receptors. The idea that the effects of DCS on fear extinction are mediated by GluN1/GluN2C receptors is consistent with a recent finding that acquisition of fear learning is impaired in GluN2C-knockout mice (Hillman et al, 2011).

Given the effects of GluN2C knockout and DCS on the acquisition and extinction of learned fear, we hypothesized that GluN2C-containing NMDA receptors have an important role in the acquisition, retention, and extinction of fear. To further evaluate the role of GluN2C receptors in fear acquisition, we tested the effects of racemic R,S-CIQ (hereafter CIQ), a GluN2C- and GluN2D-selective NMDA receptor-positive allosteric modulator (Mullasseril et al, 2010), on fear conditioning and fear extinction. Although CIQ is not an agonist at either GluN1 or GluN2 subunits, it doubles the response of GluN2C- and GluN2D-containing NMDA receptors in the presence of agonists. CIQ does not affect responses from GluN2A or GluN2B receptors. We infused CIQ bilaterally into the basolateral amygdala immediately following fear conditioning or fear extinction training and measured retention of these fear responses 1 day later. As a control, we also assessed the effects of systemic CIQ administration on spatial learning and general motor behavior, which are two potential confounds of fear learning.

\section{MATERIALS AND METHODS}

\section{Animals}

All experiments were reviewed and approved by both the Emory University and the University of Tennessee Institutional Animal Care and Use Committees, and were in compliance with the National Institutes of Health guidelines for the care and use of laboratory animals (Research IoLA, Sciences CoL, Council NR (1996)). Experiments were performed on adult (8-10 weeks), male C57Bl/6 mice purchased from Jackson Laboratory and allowed to acclimate in the vivarium for 2 weeks before surgery. Mice were group-housed with ad libitum access to food and water and maintained on a 12/12 h light/dark cycle. All experiments were performed in the light cycle. Separate groups of animals were used for pharmacokinetic, conditioned fear, and extinction experiments. A fourth group of animals was used for experiments testing spatial memory, locomotor activity, and motor function.

\section{Drugs}

CIQ was obtained from Life Chemicals (catalog no. F05350139). For intraperitoneal (i.p.) and intravenous administration, the vehicle used was $10 \%(\mathrm{v} / \mathrm{v})$ dimethylacetamide, $40 \%(\mathrm{v} / \mathrm{v})$ PEG-400, and 50\% (v/v) of a 5\% (w/v) dextrose solution in water. i.p. injections were administered at a volume of $10 \mathrm{ml} / \mathrm{kg}$. For intra-amygdala infusions, the vehicle used was 99\% (v/v) PEG-400 and 1\% (v/v) DMSO.

\section{Intracerebral Cannula Procedures}

Cannula surgeries and implantation were performed under aseptic conditions. After the mouse was fully anesthetized with ketamine-xylazine $(80 \mathrm{mg} / \mathrm{kg}: 10 \mathrm{mg} / \mathrm{kg}$, i.p.) its head was shaved to remove hair and placed into a stereotaxic frame with blunt earbars so as not to rupture the eardrum. Surgery consisted of exposing the skull and drilling small holes over the intended site of cannula implantation and also holes for the jewelers' screws that anchor the implant to the skull. Stainless-steel guide cannulae (26 gauge; Plastics One, Roanoke, VA, USA) were lowered stereotaxically to the following coordinates from bregma: anteroposterior $=$ -1.4 , mediolateral $= \pm 3.5$, and dorsoventral $=-5.1$. Dorsoventral coordinates were measured from the skull surface with the internal cannula extending $2 \mathrm{~mm}$ beyond the end of the guide cannula. Coordinates were based on the mouse brain atlas of Paxinos and Franklin (2001). Dental cement was used to hold the cannulas in place and sterilized \#0-80 jewelers' screws helped hold the cement to the skull. After surgery, the skin covering the exposed skull was closed with cyanoacrylate glue. After recovery from anesthesia, mice were given a narcotic analgesic (buprenorphine, $0.05 \mathrm{mg} / \mathrm{kg}$, s.c.) and returned to home cages for 7 days of recovery before behavioral testing. During recovery, body weight, eating, and drinking were monitored daily. Mice were also handled each day for acclimation and inspection of cannula fixture. 


\section{Pharmacokinetic Studies}

Measurement of CIQ concentrations in the plasma and brain following i.p. or i.v. administration of CIQ was performed by Ricerca Biosciences, LLC (Concord, $\mathrm{OH}$, USA). Briefly, two groups of nine $\mathrm{C} 57 \mathrm{Bl} / 6$ mice $\sim 6-8$ weeks of age were used. One group received i.v. injections of $5 \mathrm{mg} / \mathrm{kg}$ CIQ ( $5 \mathrm{ml} / \mathrm{kg}$ of a $1 \mathrm{mg} / \mathrm{ml}$ solution) via the tail vein and the other group received i.p. injections of $20 \mathrm{mg} / \mathrm{kg}$ CIQ ( $20 \mathrm{ml} / \mathrm{kg}$ of a $1 \mathrm{mg} / \mathrm{ml}$ solution). Blood and brain samples were collected at $0.5,1$, and $3 \mathrm{~h}$ after administration (three mice from each group per time point) and following isofluorane anesthesia. Whole blood was centrifuged $(\sim 1500 \mathrm{~g})$ for $10 \mathrm{~min}$ at $5{ }^{\circ} \mathrm{C}$ to obtain plasma. CIQ concentrations were measured using LC-MS/MS. Brain-toplasma ratios were calculated from the area under the CIQ concentration $v s$ time curve (AUC) as $\mathrm{AUC}_{\text {brain }} / \mathrm{AUC}_{\text {plasma }}$. AUC was calculated using the linear trapezoidal method from time 0 to the last time point $(3 \mathrm{~h})$ and had units of $(\mathrm{h} \times \mathrm{ng} / \mathrm{ml})$ for $\mathrm{AUC}_{\text {plasma }}$ and $(\mathrm{h} \times \mathrm{ng} / \mathrm{g})$ for $\mathrm{AUC}_{\text {brain. }}$ The concentration of CIQ in the plasma in $\mu \mathrm{M}$ was calculated from the measured concentration $(\mathrm{ng} / \mathrm{ml})$ and the molecular weight of CIQ (467.95).

\section{CIQ Selectivity Assays}

CIQ receptor-binding profile, $\mathrm{K}_{\mathrm{i}}$ determinations, and HERG activity were generously provided by the National Institute of Mental Health's Psychoactive Drug Screening Program (NIMH PDSP, Contract no. HHSN-271-2008-00025-C). The NIMH PDSP is directed by Bryan L Roth MD, PhD at the University of North Carolina at Chapel Hill and by Project Officer Jamie Driscol at NIMH, Bethesda, MD. For primary receptor binding and HERG activity assays, CIQ was tested at a final concentration of $10 \mu \mathrm{M}$ using assays described at http://pdsp.med.unc.edu/pdspw/binding.php. In secondary binding assays, CIQ concentration-response curves for inhibition of radioligand binding were run in duplicate and $\mathrm{IC}_{50}$ values were estimated from non-linear regression of the composite data to the equation

$$
\mathrm{Y}=\text { bottom }+\left[(\text { top }- \text { bottom }) /\left(1+10^{\mathrm{x}-\operatorname{logIC50}}\right)\right]
$$

where bottom is the residual radioligand binding, top is the amount of radioligand bound in the absence of CIQ and $\log I C 50$ is the logarithm of the $\mathrm{IC}_{50} . \mathrm{K}_{\mathrm{i}}$ values were then estimated from the Cheng-Prussoff approximation:

$$
\mathrm{K}_{\mathrm{i}}=\mathrm{IC}_{50} /\left(1+[\text { radioligand }] / \mathrm{K}_{\mathrm{D}}\right)
$$

where $\mathrm{K}_{\mathrm{D}}$ is the affinity constant of the radioligand for the receptor. CIQ was also tested on agonist-evoked responses from $\mathrm{GABA}_{\mathrm{A}}$, glycine, 5-HT3, P2X, and nicotinic ion channels recorded using two-electrode voltage clamp recordings as described (Santangelo Freel et al, 2013).

\section{Fear Conditioning Apparatus}

Mice were given fear conditioning in Med Associates rodent modular test chambers (ENV-008-VP; Med Associates St Albans, VT, USA) as previously described (Heldt and Ressler, 2006; Jones et al, 2005). Each chamber was equipped with a high frequency speaker mounted inside the chamber. The tone conditioned stimulus (CS) was a $30 \mathrm{~s}$, 70-dB SPL, 12-kHz tone delivered by GW Instek function generator (GFG-1003, Instek Corp, Chino, CA, USA). The unconditioned stimulus (US) was scrambled foot shock delivered by a current generator (Model ENV-414, MED Associates) at an intensity of $0.3 \mathrm{~mA}$ to a removable grid floor that consisted of 36 stainless steel rods $(3.2 \mathrm{~mm})$ placed $7.9 \mathrm{~mm}$ apart. Conditioned freezing responses were recorded with video cameras mounted on top of each conditioning apparatus. Footshock stimuli and freezing responses were controlled, collected, and analyzed via automated FreezeFrame3 computer software (Coulbourn, Whitehall, PA, USA).

\section{Conditioned Fear Training and Fear Retention}

Training began 1 week after cannula surgery and consisted of a single session pairing tones with mild footshocks. During fear training, mice were placed in chambers and after 5 min received five tone + shock trials (variable 2-min intertrial interval with a range of $1-3 \mathrm{~min}$ ). Immediately after training, mice received injections of either vehicle $(n=8)$ or CIQ at one of three doses $(3 \mu \mathrm{g} /$ side, $10 \mu \mathrm{g} / \mathrm{side}$, or $30 \mu \mathrm{g} /$ side; $\mathrm{ns}=8$ ) as described below. One day after training, animals were given a retention test session containing $15 \mathrm{CS}$-alone test trials (2-min intertrial interval).

\section{Fear Extinction Training And Retention}

Mice were given fear training, as described above. One day after training, mice received a short retention session consisting of three CS-alone test trials (2-min intertrial interval), the data of which were used to match groups of animals for comparable conditioned freezing levels before fear extinction training. One day after matching, mice were given an extinction session consisting of 15 CS-alone test trials (2-min intertrial interval). After training, mice received injections of either vehicle $(n=8)$ or CIQ at one of three doses ( $3 \mu \mathrm{g} / \mathrm{side}, 10 \mu \mathrm{g} / \mathrm{side}$, or $30 \mu \mathrm{g} / \mathrm{side}$; $\mathrm{ns}=9$ ). One day after the extinction session, animals were given a retention test session containing $15 \mathrm{CS}$-alone test trials.

\section{Amygdala Microinjections}

After conditioned fear or extinction training, mice were gently restrained and received amygdala injections of either vehicle or CIQ. Injections were made using an injection cannula (33 gauge cannula; Plastics One, Roanoke, VA, USA), which extended $2.0 \mathrm{~mm}$ beyond the tip of the guide cannula. Drug was delivered manually with a $5-\mu l$ Hamilton microsyringe attached to the injection cannula via polyethylene tubing (PE-10), and the administration of a volume of $0.3 \mu \mathrm{l} /$ side was delivered over a period of $60 \mathrm{~s}$ by slowly turning the microsyringe plunger. Successful infusion was confirmed by monitoring the movement of a small air bubble in the tubing. After each infusion, the injection cannula was allowed to remain for $60 \mathrm{~s}$. At the end of experiments, the animals were deeply anesthetized with ketamine-xylazine and $0.3 \mu \mathrm{l}$ of $1 \%$ Evan's blue dye was microinjected into the brain as a marker of the injection site. Five minutes after dye injections, the brains were removed, frozen in dry ice, and stored at $-80^{\circ}$ C. Serial 
coronal sections $(40 \mu \mathrm{m})$ of brains were cut on a cryostat (Leica; Nussloch, Germany) at $-20{ }^{\circ} \mathrm{C}$ and mounted on gelatin-coated slides.

\section{Morris Water Maze}

A round tub (52 inch diameter) was placed in an environment rich with extra maze cues and filled with water at $25^{\circ} \mathrm{C}$. An invisible escape platform $1 \mathrm{~cm}$ below the water surface was located in the same spatial location independent of the start position on a particular trial. In this manner, mice were able to utilize extra maze cues to determine the platform's location. Each mouse was given four trials per day for 5 days (15-min intertrial interval). Each day, mice were injected i.p. with $10 \mathrm{mg} / \mathrm{kg}$ CIQ $(n=10)$ or vehicle $(n=10) 30 \mathrm{~min}$ before the first trial. Mice were placed in the water maze with their paws touching the wall from four different starting positions (N, $\mathrm{S}, \mathrm{E}$, and $\mathrm{W}$ ). The maximum trial length was $60 \mathrm{~s}$ and if the mice did not reach the platform in the allotted time, they were manually guided to it. Upon reaching the escape platform, mice were left on it for an additional $5 \mathrm{~s}$ to allow for survey of the spatial cues in the environment to guide future navigation to the platform. On the day following the 5 days of task acquisition, a probe trial was presented in the absence of drug during which the platform was removed and the amount of time and distance swam in each quadrant of the maze was measured over $60 \mathrm{~s}$. All trials were videotaped and performance analyzed by MazeScan (CleverSys, Reston, VA, USA).

\section{Locomotor Activity}

Mice were given i.p. injections of $10 \mathrm{mg} / \mathrm{kg}$ CIQ $(n=8)$ or vehicle $(n=8) 30 \mathrm{~min}$ before being placed in the Plexiglass activity cages with cob bedding and infrared photobeams (San Diego Instruments, San Diego, CA, USA) for $2 \mathrm{~h}$. Ambulations were defined as consecutive beam breaks and counted by an interfacing computer.

\section{Rotarod}

Mice were given two practice trials on a rotating cylinder at the slow rotational speed of 4 r.p.m. Mice were given i.p. injections of $10 \mathrm{mg} / \mathrm{kg}$ CIQ $(n=8)$ or vehicle $(n=8)$ and 30 min later placed on the cylinder rotating at 4 r.p.m and rotational speed was gradually increased over a 5-min test session up to a maximum rotational speed of 40 r.p.m. Latency to fall off of the accelerating rotarod was measured.

\section{Behavioral Data Analyses}

The data from acquisition and retention of conditioned freezing were analyzed by means of a repeated measure ANOVA with treatment (vehicle, 3,10 , and $30 \mu \mathrm{g} /$ side) as a between-subjects factor and training trial (CS trials) as a within-subjects factor. The data from acquisition of extinction were analyzed by means of a repeated measure ANOVA with treatment group as a between-subjects factor and training trial (CS trials 1-15) as a within-subjects factor. Extinction was also assessed with an ANOVA with treatment and test trials (trials 1-5, trials 11-15) as factors.
Other follow-up analyses were done, when appropriate, by one-way ANOVA simple effects and Dunnett's $t$-tests. The effect of CIQ on locomotor activity was analyzed by a repeated measure two-way ANOVA with treatment (vehicle or CIQ) as a between-subjects factor and time as a withinsubjects factor. Rotarod performance was analyzed using an unpaired $t$-test. Latency, path length, and swim speed performance in the Morris water maze were analyzed by two-way repeated measures ANOVA with training day as a within-subjects factor and treatment (vehicle or CIQ) as a between-subjects factor. The time spent in each quadrant of the water maze on the probe trial was analyzed by two-way repeated measures ANOVA with treatment (vehicle or CIQ) as a within-subjects factor and quadrant as a withinsubjects factor.

\section{RESULTS}

\section{CIQ Selectively Enhances Responses Through GluN2C/ D-Containing NMDA Receptors}

CIQ potentiates responses from GluN2C and GluN2D NMDA receptors approximately twofold with an $\mathrm{EC}_{50}$ value of 3-5 $\mu \mathrm{M}$ (Mullasseril et al, 2010). CIQ at $20 \mu \mathrm{M}$ showed no effect on AMPA or kainate receptors (Mullasseril et al, 2010), suggesting a high degree of selectivity. To further evaluate the selectivity of CIQ, we measured the effects of CIQ on agonist-evoked currents from several ion channels using two-electrode voltage-clamp recordings. CIQ $(10 \mu \mathrm{M})$ had no effect on currents from $\mathrm{GABA}_{\mathrm{A}}, \mathrm{GABA}_{\mathrm{C}}$, glycine, $5-\mathrm{HT}_{3} \mathrm{~A}$, or $\mathrm{P} 2 \times 2$ receptors expressed in Xenopus oocytes (Figure 1a). However, $10 \mu \mathrm{M}$ CIQ caused modest inhibition at nicotinic acetylcholine receptors (Figure 1a). To additionally assess whether CIQ might affect responses from other neurological targets, we screened CIQ at $10 \mu \mathrm{m}$ for actions at 62 receptors and pumps that are expressed in the CNS (Table 1). The screen involved displacement of a radioligand from the various targets. CIQ only showed effects on radioligands for the $\kappa$ opioid receptor, the $5-\mathrm{HT}_{2 \mathrm{~A}}, 5-\mathrm{HT}_{2 \mathrm{~B}}$, and $5-\mathrm{HT}_{6}$ receptors, and the norepinephrine transporter (NET). In a secondary concentrationresponse binding assay, CIQ displaced ligands for $\kappa$ opioid receptors with a $\mathrm{K}_{\mathrm{i}}$ of $3.6 \pm 0.6 \mu \mathrm{M}, 5-\mathrm{HT}_{2 \mathrm{~B}}$ receptors with a $\mathrm{K}_{\mathrm{i}}$ of $2.8 \pm 0.2 \mu \mathrm{M}$, and $5-\mathrm{HT}_{6}$ receptors with a $\mathrm{K}_{\mathrm{i}}$ of $0.51 \pm 0.04 \mu \mathrm{M}$, whereas the $\mathrm{K}_{\mathrm{i}}$ of CIQ at NET and $5-\mathrm{HT}_{2 \mathrm{~A}}$ receptors was $>10 \mu \mathrm{m}$. These experiments suggest that CIQ is fairly selective, with off-target activity found in only 8 out of 73 targets.

\section{Histology}

Of the 50 mice that received injections, 3 were excluded from statistical analysis because of extensive necrosis extending from the tip of the guide cannula or misplacement. Of these three mice, one received CIQ at $3 \mu \mathrm{g} /$ side after fear acquisition, one received CIQ at $3 \mu \mathrm{g} / \mathrm{side}$ after fear extinction, and one received CIQ at $30 \mu \mathrm{g} / \mathrm{side}$ after fear extinction. Inspection of the remaining brain sections revealed that dye injections were centered within the lateral and basolateral nuclei of the amygdala. In 10 brain sections, dye was also evident in adjacent areas including the basomedial, central nuclei of the 

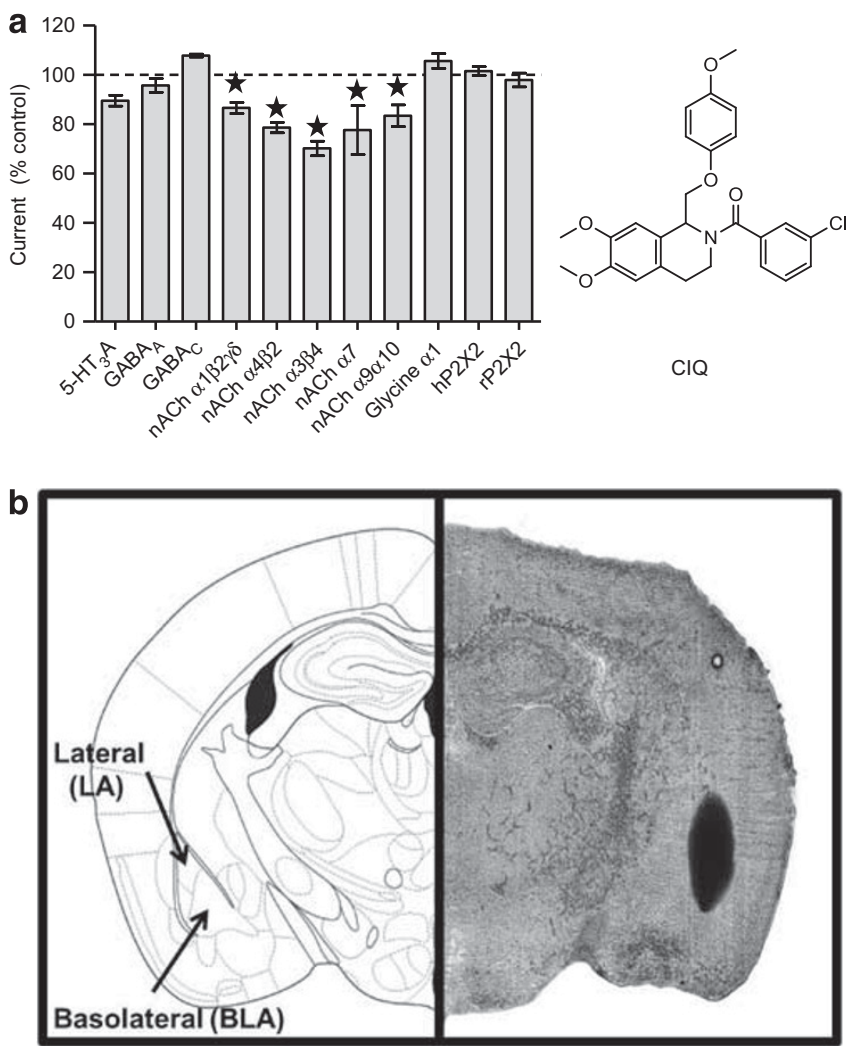

Figure I (a) The indicated ion channels were expressed in Xenopus oocytes, and agonist-evoked currents were recorded using two-electrode voltage clamp. Subsequently, I $0 \mu \mathrm{M} \mathrm{ClQ}$ was co-applied with agonists and the current response was measured and normalized to the agonist-alone current (control). * indicates significantly different from 100\% $(p<0.05$, one-way ANOVA with Dunnett's post-test). Data are from 3-9 oocytes per ion channel. Right, the chemical structure of the GluN2C/GluN2Dselective allosteric potentiator $\mathrm{ClQ}$ is shown. (b) Photomicrograph of a coronal mouse brain section and corresponding atlas plate (Paxinos and Franklin (200I)) which shows the typical site and spread of microinjections as assessed by stain injections. Vehicle and all doses of ClQ were injected at a volume of $0.3 \mu \mathrm{l}$ into the lateral (LA) and basolateral (BLA) amygdala.

amygdala, and/or caudate putamen. An evaluation of the standardized residuals by group revealed that the dependent variables of animals with spread of dye to collateral areas did not differ substantially from their respective group means (within-cells $z s<2.0$ ). Figure $1 \mathrm{~b}$ shows representative photomicrographs of the dye-injected brain sections that example the typical site and spread of microinjections.

\section{Conditioned Fear Training And Fear Retention}

As seen in Figure 2a, levels of conditioned freezing during the fear training session did not differ among animals given post-training injections of either $3 \mu \mathrm{g}$ (CIQ-3), $10 \mu \mathrm{g}$ (CIQ-10), $30 \mu \mathrm{g}$ (CIQ-30), or vehicle (VEH), $p$-values $>0.05$. However, when mice were tested 1 day after post-training injections, treatment groups differed in levels of fear (Figure 2b). This finding was supported by a repeated measures ANOVA that yielded a significant main effect of treatment, $F(3,27)=4.01, p<0.05$. The main effect of trial was also reliable, indicating an overall decrease in fear across the CS-alone trials, $F(4,108)=15.22$, $p<0.01$. The Treatment $\times$ trial Interaction was insignificant, $F(12,108)=0.65, \quad p>0.05$. Follow-up Dunnett's $t$-tests revealed that CIQ-10 and CIQ-30 mice showed higher levels of conditioned freezing when compared with the vehicle group, $p$-values $<0.05$. In contrast, the level of fear in CIQ -3 mice was similar to the vehicle group, $p>0.05$. Together, these findings suggest that post-training intraamygdala infusions of CIQ dose-dependently enhanced the retention of fear when assessed $24 \mathrm{~h}$ after training.

\section{Fear Extinction Training and Retention}

Before extinction training, mice were given fear training and matched for comparable conditioned freezing levels. Mean percent levels of conditioned freezing before extinction training were as follows (SEM in parentheses): CIQ-3 = 24.7 (6.1), CIQ-10 =26.4(5.2), CIQ-30 =27.6(7.1), and vehicle $=24.5(6.8)$. As illustrated in Figure $3 \mathrm{a}$, matched groups showed similar levels of fear extinction before treatment. During the extinction training session, all groups displayed significantly less freezing with repeated CS-alone presentations, indicative of fear extinction. These findings were supported by a repeated measures ANOVA which yielded significant main effects of trial, $F(14,420)=9.86$; $p<0.01$ but no treatment or Treatment $\times$ Trial interaction, $F$-values $<1.0, p$-values $>0.05)$. As shown in Figure $3 b$, all groups displayed significantly less freezing at the end of the training session (CS trials 11-15) compared with the start of the session (CS trials $1-5$; $p$-values $>0.05$ ). When tested 1 day after extinction training and treatment, significant differences in levels of conditioned freezing were displayed by treatment groups (Figure 3c). An ANOVA showed a significant main effect of treatment, $F(3,30)=3.10, p<0.05$. The main effect of trial was also reliable, indicating an overall decrease in fear across the CS trials, $F(4,120)=2.87$, $p<0.05$. The Treatment $\times$ Trial interaction was insignificant, $F(12,120)=0.59, P>0.05$. Dunnett's $t$-tests revealed that mice that received $10 \mu \mathrm{g}$ injections after extinction training (CIQ-10) displayed less conditioned freezing than vehicle animals, $p<0.05$. No significant differences were detected between the vehicle group and the other treatment groups ( $p$-values $>0.05)$. Together, these analyses indicate that post extinction training, intra-amygdala infusions of CIQ dose-dependently enhanced the retention of fear extinction when assessed $24 \mathrm{~h}$ after training.

\section{Systemic Administration Of CIQ Does Not Affect Morris Water Maze Learning}

To determine whether the effects of CIQ were specific to fear learning, we tested the effects of CIQ on performance in the Morris water maze, a spatial memory and learning task. Because spatial learning is dependent on brain areas other than the amygdala, such as the hippocampus, we chose to administer CIQ systemically to look for possible effects of drug in a wide range of neural systems. To assess whether CIQ crosses the blood-brain barrier and to calculate the half-life of CIQ, we injected CIQ intravenously $(5 \mathrm{mg} / \mathrm{kg}$ ) or intraperitoneally $(20 \mathrm{mg} / \mathrm{kg})$ to mice and measured the concentrations of CIQ in the plasma (Figure 4a) and in the brain (Figure 4b). CIQ had a half-life of $46 \mathrm{~min}$ when 
Table I Selectivity of $\mathrm{ClQ}$ Across Neuronal Receptors

\begin{tabular}{|c|c|c|c|}
\hline Receptor & Assay & Inhibition (\%) & $\mathbf{K}_{\mathbf{i}}(\mu \mathrm{M})$ \\
\hline $5-\mathrm{HT}_{\mid \mathrm{A}}$ & RLB & - & \\
\hline $5-\mathrm{HT}_{\mathrm{IB}}$ & RLB & - & \\
\hline $5-\mathrm{HT}_{I D}$ & RLB & 27 & \\
\hline $5-\mathrm{HT}_{\mathrm{IE}}$ & RLB & - & \\
\hline $5-\mathrm{HT}_{2 \mathrm{~A}}$ & RLB & 83 & $>10$ \\
\hline $5-\mathrm{HT}_{2 \mathrm{~B}}$ & RLB & 64 & 2.8 \\
\hline $5-\mathrm{HT}_{2 \mathrm{C}}$ & RLB & 35 & \\
\hline $5-\mathrm{HT}_{3}$ & RLB & - & \\
\hline $5-\mathrm{HT}_{4}$ & RLB & 17 & \\
\hline $5-\mathrm{HT}_{5 \mathrm{~A}}$ & RLB & 27 & \\
\hline $5-\mathrm{HT}_{6}$ & RLB & 98 & 0.51 \\
\hline $5-\mathrm{HT}_{7}$ & RLB & - & \\
\hline$\alpha 2 \beta 2$ & RLB & 6 & \\
\hline$\alpha 2 \beta 4$ & RLB & - & \\
\hline$\alpha 3 \beta 2$ & RLB & - & \\
\hline$\alpha 3 \beta 4$ & RLB & - & \\
\hline$\alpha 4 \beta 2$ & RLB & - & \\
\hline$\alpha 4 \beta 2$ & RLB & - & \\
\hline$\alpha 4 \beta 4$ & RLB & - & \\
\hline$\alpha 7$ & RLB & - & \\
\hline$\alpha_{\mid A}$ adrenoceptor & RLB & - & \\
\hline$\alpha_{\text {IB }}$ adrenoceptor & RLB & 25 & \\
\hline$\alpha_{I D}$ adrenoceptor & RLB & 21 & \\
\hline$\alpha_{2 A}$ adrenoceptor & RLB & - & \\
\hline$\alpha_{2 B}$ adrenoceptor & RLB & 37 & \\
\hline$\alpha_{2 C}$ adrenoceptor & RLB & 39 & \\
\hline$\beta_{1}$ adrenoceptor & RLB & 10 & \\
\hline$\beta_{2}$ adrenoceptor & RLB & - & \\
\hline$\beta_{3}$ adrenoceptor & RLB & 41 & \\
\hline Benzodiazepine site & RLB & 29 & \\
\hline $\mathrm{Ca}^{2+}$ channel & RLB & 28 & \\
\hline $\mathrm{CB}_{1}$ & RLB & 32 & \\
\hline $\mathrm{CB}_{2}$ & RLB & 44 & \\
\hline$D_{1}$ & RLB & 41 & \\
\hline$D_{2}$ & RLB & 24 & \\
\hline$D_{3}$ & RLB & 14 & \\
\hline$D_{4}$ & RLB & 32 & \\
\hline$D_{5}$ & RLB & 23 & \\
\hline DAT & RLB & 29 & \\
\hline$\delta$ opioid receptor & RLB & 26 & \\
\hline $\mathrm{GABA}_{\mathrm{A}}$ & RLB & 25 & \\
\hline $\mathrm{GABA}_{\mathrm{B}}$ & RLB & - & \\
\hline $\mathrm{H}_{1}$ & RLB & 33 & \\
\hline $\mathrm{H}_{2}$ & RLB & 44 & \\
\hline $\mathrm{H}_{3}$ & RLB & 26 & \\
\hline $\mathrm{H}_{4}$ & RLB & 13 & \\
\hline HERG $\mathrm{K}^{+}$channel & Functional & 15.1 & \\
\hline$\kappa$ opioid receptor & RLB & 67 & 3.6 \\
\hline$M_{1}$ & RLB & - & \\
\hline$M_{2}$ & RLB & - & \\
\hline$M_{3}$ & RLB & - & \\
\hline
\end{tabular}

Table I (Continued)

\begin{tabular}{lccc}
\hline Receptor & Assay & Inhibition (\%) & $\mathbf{K}_{\mathbf{i}}(\boldsymbol{\mu} \mathbf{M})$ \\
\hline$M_{4}$ & RLB & - & \\
$M_{5}$ & RLB & 37 & \\
$\mu$ opioid receptor & RLB & 28 & $>10$ \\
NET & RLB & 75 & \\
NMDA receptor pore & RLB & - & \\
OT oxytocin receptor & RLB & - & \\
SERT & RLB & 9 & \\
$\sigma_{1}$ & RLB & 27 & \\
$\sigma_{2}$ & RLB & - \\
$V_{\text {IA }}$ & RLB & - \\
$V_{\text {IB }}$ & RLB & 13 \\
$V_{2}$ & RLB & - \\
\hline
\end{tabular}

$\mathrm{CIQ}(10 \mu \mathrm{M})$ was screened for binding to 62 receptors, transporters, or ion channels in primary radioligand-binding assays and the percent inhibition of radioligand is shown in Table I. For targets displaying greater than $50 \%$ inhibition by $10 \mu \mathrm{M} \mathrm{ClQ}$, secondary concentration-binding curves were performed to determine the $\mathrm{IC}_{50}$ for displacement of radioligand by $\mathrm{ClQ}$. Data are mean inhibition for four experiments. - indicates less than $5 \%$ inhibition with $10 \mu \mathrm{M}$ $\mathrm{CIQ}$. RLB designates radioligand-binding assay. Functional indicates an assay based on a dye whose fluorescence intensity is sensitive to the membrane potential (see PubChem BioAssay ID 376 http://pubchem.ncbi.nlm.nih.gov/assay/ assay. coi?aid=376).

administered i.v. and $81 \mathrm{~min}$ after i.p. injection. CIQ concentrations in the brain peaked $30 \mathrm{~min}$ after administration for both i.v. and i.p. routes and decreased with firstorder kinetics. When injected i.p., CIQ had a bioavailability of 0.42 and the brain-to-plasma concentration ratio was 5.4.

On the basis of these results, CIQ $(10 \mathrm{mg} / \mathrm{kg})$ was injected i.p. $30 \mathrm{~min}$ before training in the water maze.

As seen in Figure 4c, both vehicle and CIQ mice showed similar latencies to mount the platform during the 5-day training sessions levels. Overall, both treatment groups showed decreases in latencies to mount the platform over time, $\mathrm{F}(4,72)=12.48 ; p<0.01$; however, neither the main effect of treatment nor Treatment $\times$ Time interaction were significant, $F$-values $<1.0, p$-values $>0.05$. Likewise, a within-subjects factor ANOVA on swim speed revealed no main effect of treatment or Treatment $\times$ Time interaction, $F$-values $<1.0, p$-values $>0.05$ (data not shown). The significant main effect of time on swim speed, $F(4,72)=11.75$; $p<0.0001$, likely reflected an increase of speed after training Day 1. In the case of swimming path length, the ANOVA revealed significant main effects of time, $\mathrm{F}(4,72)=5.19$; $p<0.01$, and treatment, $\mathrm{F}(1,18)=5.13 ; p=0.036$; whereas, the Treatment $\times$ Time interaction was not significant, $\mathrm{F}(4,72)=0.55 ; P>0.05$. Both vehicle and CIQ mice showed a decrease in swimming path length over time; however, the path length for CIQ mice was generally slightly longer (data not shown).

To assess spatial memory, mice were placed in the water maze $24 \mathrm{~h}$ after the last training day in the absence of drug, and the time spent in each quadrant was measured. As illustrated in Figure 4d, both CIQ and vehicle mice were similar in the amount of time spent in each quadrant. The main effect of drug and the Drug $\times$ Quadrant 

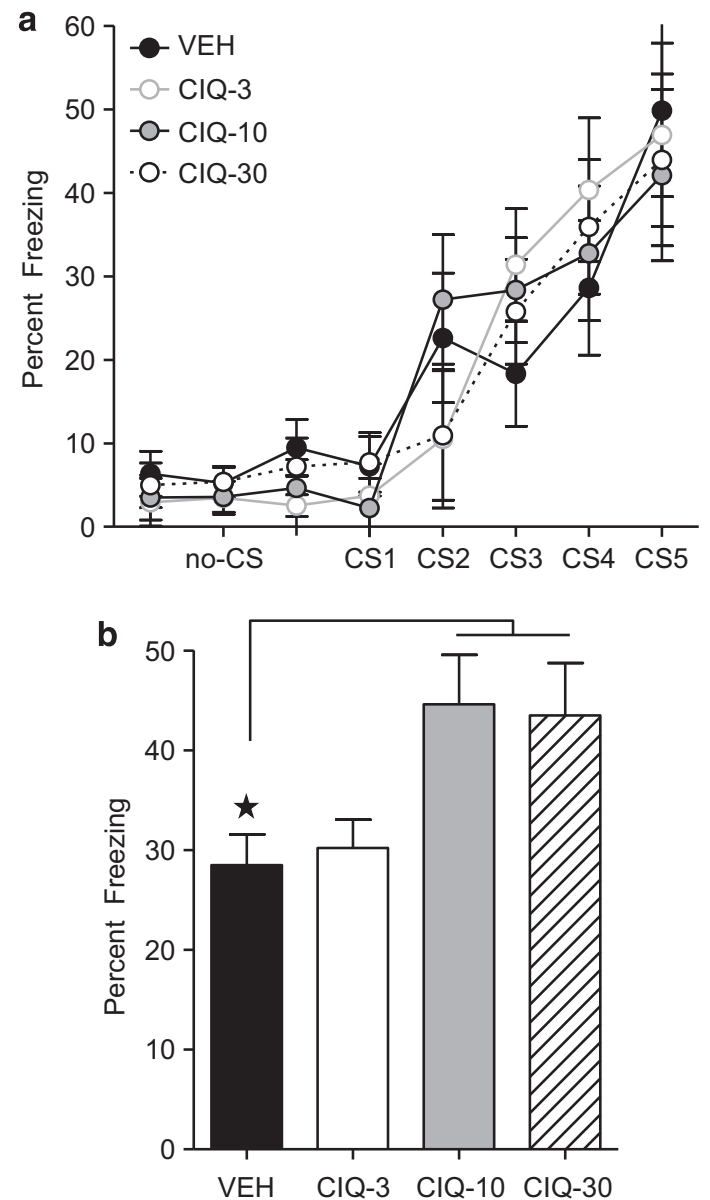

Figure 2 (a) Levels of conditioned freezing during the fear training did not differ among animals given post-training injections of $3 \mu \mathrm{g}$ (ClQ-3), $10 \mu \mathrm{g}$ (ClQ- I0), $30 \mu \mathrm{g}$ (CIQ-30), or vehicle (VEH) injections. (b) When mice were tested I day after post-training amygdala injections, CIQ- 10 and CIQ-30 mice showed higher levels of conditioned freezing when compared with the VEH group, $p$-values $<0.05$. Number of animals per treatment condition: $\mathrm{VEH}(n=8), \mathrm{ClQ}-3 \quad(n=7), \mathrm{ClQ}-10(n=8)$, and CIQ-30 $(n=8)$. Error bars denote one SEM. Star indicates that the difference between groups was statistically significant $(p<0.05)$.

interaction were statistically nonsignificant, $F$-values $<1.0$, $p$-values $>0.05$. The main effect of Quadrant was significant, $F(3,54)=13.80 ; p<0.01$, indicating differences in amount of time spent in each quadrant.

\section{CIQ Does Not Affect Locomotor Activity or Coordinated Movement}

As GluN2C-containing receptors are abundantly expressed in the cerebellum, a region of the brain important for movement, we also tested whether CIQ was capable of altering locomotor behavior or movement, a potential confound in the interpretation of our freezing measure in the fear learning paradigm. CIQ $(10 \mathrm{mg} / \mathrm{kg}$, i.p.) caused no detectable change in locomotor activity as revealed by a lack of main effect for drug and Drug $\times$ Time interaction, $F$ values $<1.0, p$-values $>0.05$ ). The significant main effects of time, $F(7,98)=28.74 ; p<0.01$, reflected a decrease in the locomotor behavior collapsed across drug treatment
(Figure 5a). For coordinated movement, as measured on the rotarod, an unpaired $t$-test indicated no drug effect on time spent on the rotarod, $t(14)=0.89, P>0.05$, suggesting that CIQ treatment did not induce an "ataxic-like" behavior (Figure 5b). Together, these data suggest that the effects of CIQ on learning were unlikely to involve any confounding general effects on the motor system.

\section{DISCUSSION}

The most important finding of this study was that NMDA receptors containing either the GluN2C or GluN2D subunit appear to be involved in fear learning. The data suggest that potentiation of GluN2C/D receptor responses can enhance fear acquisition and increase fear extinction. Thus, we suggest that these receptors are involved in the circuitry underlying this behavior. Furthermore, the local injection of CIQ implicates the target as being in or close to the amygdala. This study also extends previous data on the selectivity of CIQ for GluN2C/2D-containing NMDA receptors to show that CIQ only binds 3 of 83 CNS receptors or transporters with potency similar to the potency of CIQ on GluN2C/2D receptors. We additionally show that CIQ is brain penetrant when injected intraperitoneally.

A number of lines of evidence suggest that the GluN2C subunit is particularly important in the observed effects of CIQ. The effects of CIQ on fear extinction are consistent with published data using DCS to facilitate extinction retention (Ledgerwood et al, 2003; Myers et al, 2011; Walker et al, 2002). In extinction, NMDA receptors seem to have a consolidation-related role on the basis of evidence that DCS facilitates extinction retention when given post extinction at intervals up to $120 \mathrm{~min}$ (Ledgerwood et al, 2003). On the basis of findings that intra-amygdala injections of DCS facilitate the extinction of fear (Walker et al, 2002), coupled with the observation that DCS elicits responses from GluN2C receptors (but not GluN2A, 2B, or 2D receptors) that are greater than responses caused by the endogenous co-agonist glycine, we propose that CIQ facilitates extinction by potentiating GluN2C receptors. Future studies will be required to determine what downstream signaling cascades such as MAPK and PI3K, which are important for DCS actions (Yang and Lu, 2005), mediate the effects of CIQ.

In addition to extinction, we found that intra-BLA injections of CIQ facilitated the consolidation of conditioned fear to a tone CS in mice. The finding that local injections of CIQ enhanced retention of fear, in addition to extinction, is not entirely unexpected. Acquisition and extinction of learned fear are learning processes that, like all learning processes, require encoding, storage, and retrieval. Importantly, NMDA receptor activation is required for both processes (for reviews see, Johansen et al, 2011; Myers and Davis, 2007). Evidence for a role of GluN2C in fear learning is provided by recent studies of GluN2C-knockout mice (Hillman et al, 2011). These studies demonstrated that GluN2C-knockout mice show impaired acquisition of fear conditioning and concomitant lack of fear conditioninginduced plasticity at thalamo-amygdala synapses. The deficit in fear learning was observed for both cued and contextual conditioned fear and was observed with both a 

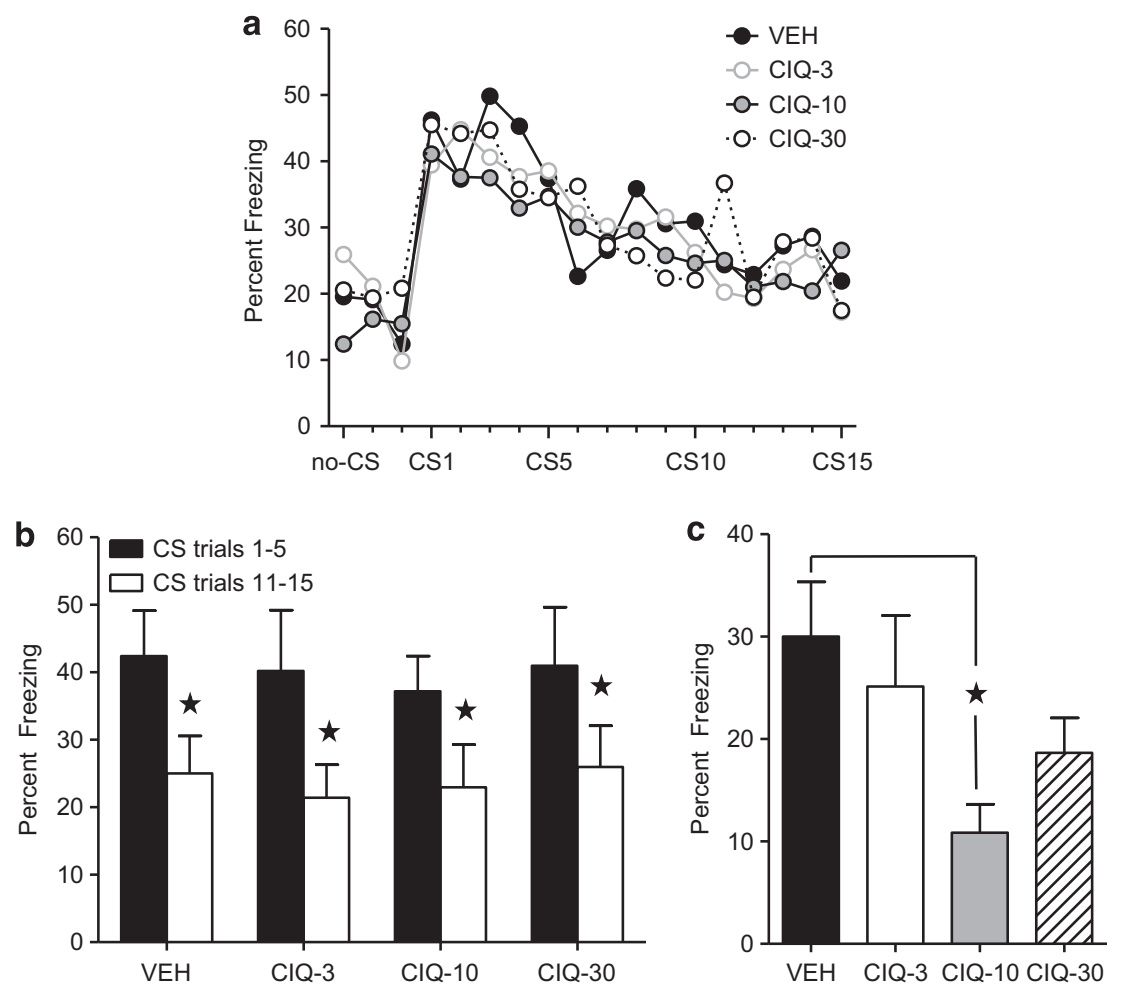

Figure 3 (a) Mice matched for comparable conditioned freezing levels showed similar rates of fear extinction before treatment. After extinction, mice were given amygdala injections of $3 \mu \mathrm{g}$ (ClQ-3), $10 \mu \mathrm{g}(\mathrm{ClQ}-10), 30 \mu \mathrm{g}(\mathrm{ClQ}-30)$, or vehicle (VEH). (b) All groups displayed significantly less freezing at the end of the training session (CS trials II-15) compared with the start of the session (conditioned stimulus, CS trials I-5). (c) When tested I day after treatment, mice that received $10 \mu$ g injections after extinction training $(\mathrm{ClQ}-\mathrm{IO})$ displayed less conditioned freezing than vehicle animals. No significant differences were detected between the vehicle group and the other treatment groups ( $p$-values $>0.05)$. Number of animals per treatment condition: VEH $(n=9)$, CIQ-3 $(n=8)$, CIQ-IO $(n=9)$, and CIQ-30 $(n=8)$. Error bars denote SEM. Star indicates that the difference between groups was statistically significant $(p<0.05)$.

tone and a light as the CS (Hillman et al, 2011). These data, together with the enhanced retention of conditioned fear we observed after local infusion of CIQ in the amygdala, suggest that the potentiation of GluN2C receptors in the BLA might also underlie the effects of CIQ on fear conditioning. Alternatively, it is possible that the strong positive allosteric modulator effect of CIQ on GluN2Dcontaining NMDA receptors may mediate the fear-enhancing effects. Futures studies with GluN2C- and/or GluN2Dknockout mice might help resolve this issue. However, it is worth noting that systemic injections of DCS have been shown to enhance conditioned fear in other animal learning models (Flood et al, 1992; Land and Riccio, 1999). DCS administration following conditioned fear training has also been shown to facilitate recall of the conditioned fear in humans (Kalisch et al, 2009). Given that NMDA receptors are expressed in a cellular- and subcellular-specific manner (for reviews see, Gladding and Raymond, 2011; Paoletti et al, 2013; Sanz-Clemente et al, 2013), determining what inputs to the BLA and neuronal subtype CIQ acts on to enhance fear conditioning merits further investigation.

The data from the water maze spatial learning and memory task suggest that potentiation of GluN2C/2D receptors does not lead to increased learning and memory in the Morris water maze. Positive effects of DCS on hippocampal-dependent learning tasks have been demon- strated in studies utilizing single training session paradigms. For example, acute pre- and/or post-training systemic injections of DCS dose-dependently improve performance on object and location recognition tasks (Assini et al, 2009; Bado et al, 2011; Zlomuzica et al, 2007). In addition, DCS improved long-term retention in a one-trial inhibitory avoidance, a hippocampus-dependent form of single-trial learning (Land and Riccio, 1999; Monahan et al, 1989). By contrast, the Morris water maze examines memory across multiple days using a daily injection protocol, and we cannot rule out the possibility that the water maze might thereby be less sensitive to the potential memory-enhancing effects of CIQ. Consistent with this possibility, past studies have shown that, although DCS can reverse water maze learning deficits in aged and memory-impaired rats, it has little effect to no effects on acquisition and performance of control rats (Aura et al, 1998; Pitkanen et al, 1995; Sunyer et al, 2008). Although GluN2C and GluN2D are not expressed in hippocampal pyramidal neurons (Gray et al, 2011; Monyer et al, 1994), expression has been observed in hippocampal interneurons (Karavanova et al, 2007; Monyer et al, 1994). CIQ might therefore have more pronounced enhancement in behavioral tasks dependent on hippocampal interneuron function, such as reward alternation on the T-maze (Korotkova et al, 2010). Future studies using other hippocampal-dependent 

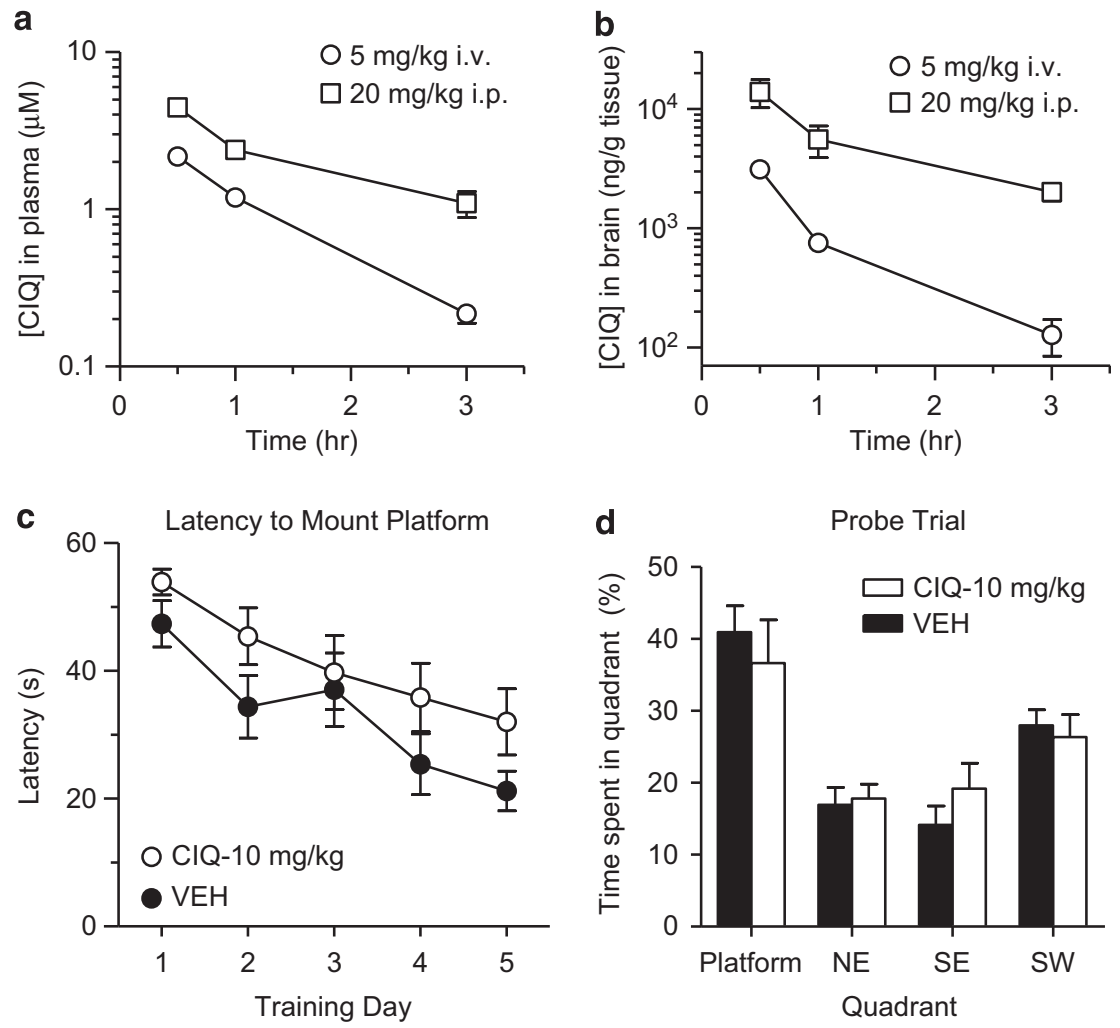

Figure 4 (a) The concentration of CIQ in the blood plasma was determined by LC-MS/MS at 0.5, I, and $3 \mathrm{~h}$ after injection of the indicated doses. Intravenous (i.v.) data are from three mice per time point and intraperitoneal (i.p.) data are from I-3 mice per time point. (b) The amount of ClQ in wholebrain tissue was determined at 0.5, I, and $3 \mathrm{~h}$ after injection of $\mathrm{ClQ}$ as indicated. Data for i.v. and i.p. injections are from three animals per time point. (c) Mice were trained in the Morris water maze and the latency to mount the hidden platform was measured. Mice received i.p. injection of I0 mg/kg ClQ (ClQ- I0 $\mathrm{mg} / \mathrm{kg}$ ) or vehicle $(\mathrm{VEH}) 30$ min before each training session. (d) One day after the last training day, mice were placed back in the water maze with the platform removed and the time spent in each quadrant was measured. Error bars denote SEM. Data are from 10 animals per treatment (VEH or CIQ- I 0 mg/ $\mathrm{kg}$ ).

learning tasks and multiple doses levels will be required to more fully examine the effects of CIQ on learning and/or memory processes.

Although the enhanced retention of both fear conditioning and fear extinction observed with amygdalar infusions of CIQ are consistent with potentiation of GluN2C receptors, CIQ also bound to $5-\mathrm{HT}_{2 \mathrm{~B}}, 5-\mathrm{HT}_{6}$, and $\kappa$-opioid receptors in radioligand assays with potencies similar to its potency on GluN2C/2D (see Table 1). Thus, we cannot fully rule out the possibility that the behavioral effects of posttraining amygdala CIQ injections were not influenced by off-target effects. Future studies are required to determine whether CIQ enhances (eg, agonist) or inhibits (eg, antagonist) the function of these receptors. Nevertheless, some consideration needs to be given to the possibility that CIQ influenced the activity of receptors previously shown to be involved in learning and memory, including $5-\mathrm{HT}_{2}$ and $\kappa$-opioid receptors.

Several studies indicate that $5-\mathrm{HT}_{2}$ receptors in the amygdala have a significant role in learning and memory processes depending on whether it is administered before training, during memory consolidation, or before the testing (for review, see Bombardi and Di Giovanni, 2013; Homberg, 2012; Montezinho et al, 2010). Much of this work has focused on $5-\mathrm{HT}_{2 \mathrm{~A}}$ receptors, which are located in the amygdala on both pyramidal cells and inhibitory interneurons (Bombardi, 2011; Bombardi and Di Giovanni, 2013;
McDonald and Mascagni, 2007). Electrophysiological studies indicate that serotonin acting on pyramidal $5-\mathrm{HT}_{2 \mathrm{~A}}$ receptors in the BLA increases cell firing (Eison and Mullins, 1995; Stein et al, 2000) and enhances NMDA receptor-dependent synaptic potentiation, which can be blocked by $5-\mathrm{HT}_{2}$ receptor antagonists (Chen et al, 2003). 5$\mathrm{HT}_{2}$ receptor activation of inhibitory interneurons increases the frequency of rhythmic IPSPs and regulates neural oscillations in the amygdala (Rainnie, 1999; Sokal et al, 2005). Recently, it has been shown that post-training injections of $5-\mathrm{HT}_{2 \mathrm{~A}}$ receptor agonists facilitates cue and contextual trace fear and novel object recognition, possibly by facilitating the consolidation processes (Zhang et al, 2013). By contrast, post-training administration of the 5$\mathrm{HT}_{2 \mathrm{~A}}$ receptor antagonist disrupted cue trace fear (Zhang et al, 2013).

In addition, $5-\mathrm{HT}_{6}$ receptors have a role in learning and memory (for reviews see, King et al, 2008; Mitchell and Neumaier, 2005), and a few studies have evaluated contribution of 5- $\mathrm{HT}_{6}$ receptors to emotional learning. Ro 4368554, a $5-\mathrm{HT}_{6}$ receptor antagonist, alleviated memory deficits caused by scopolamine in amygdala-dependent fear conditioning as measured by fear potentiated startle (Mitchell and Neumaier, 2008). By contrast, two other 5$\mathrm{HT}_{6}$ receptor antagonists, Ro $04-6790$ and SB-271046, failed to alleviate scopolamine-induced deficits in hippocampaldependent contextual fear conditioning (Lindner et al, 
a

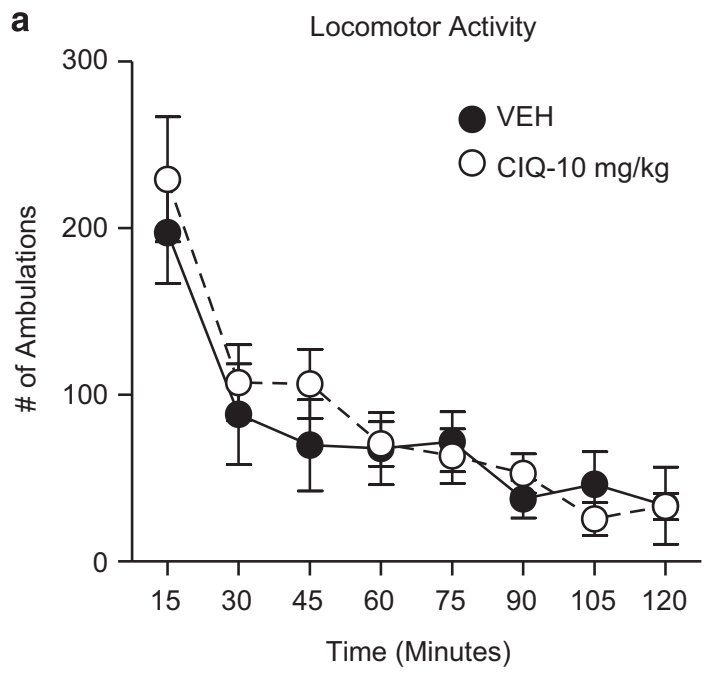

b

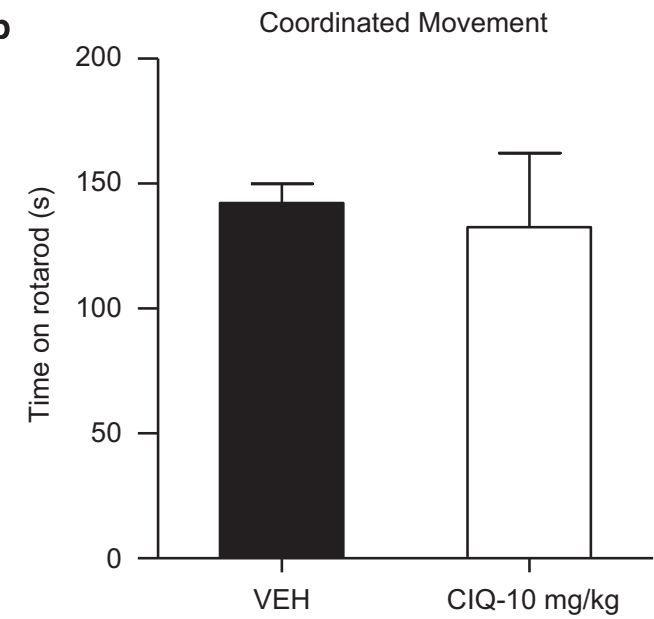

Figure 5 (a) Mice were injected with $10 \mathrm{mg} / \mathrm{kg} \mathrm{ClQ}(\mathrm{ClQ}-10 \mathrm{mg} / \mathrm{kg})$ or vehicle (VEH) intraperitoneal (i.p.) $30 \mathrm{~min}$ before being placed in a novel chamber and ambulations over the next $2 \mathrm{~h}$ counted as the number of beam breaks. (b) Mice were injected with $\mathrm{ClQ}$ or vehicle i.p. 30 min before being placed on accelerating rotarod and the latency to falling off the rotarod was measured. Error bars denote SEM. Data are from eight animals per treatment (vehicle or $\mathrm{ClQ}$ ).

2003). However, in both of these studies, the $5-\mathrm{HT}_{6}$ receptor antagonists alone had no effect on fear conditioning. Nevertheless, given evidence that BLA serotonergic transmission influences memory processing, it is possible that CIQ influence on $5-\mathrm{HT}_{2}$ and $5-\mathrm{HT}_{6}$ receptors may have contributed to the enhancement of conditioned fear and extinction.

The possibility that CIQ influenced $\kappa$-opioid transmission should also be addressed. Although $\mu$-opioid receptors are known to have a critical role in Pavlovian fear and extinction (McNally, 2009), much less is about the role of $\kappa$-receptors in these processes. The $\kappa$-opioid receptor and its endogenous ligand dynorphin are expressed throughout brain areas involved in fear and anxiety, including in the BLA (Butelman et al, 2012; Fallon and Leslie, 1986; Jamensky and Gianoulakis, 1997; Mansour et al, 1995). Systemic administration of $\kappa$-opioid receptor antagonists produces anxiolytic-like effects in models and reduces conditioned fear in rats when given before training (Carr and Lucki, 2010; Knoll et al, 2007; Knoll et al, 2011). Furthermore, disrupting opioid signaling using local infusions of a $\kappa$-opioid antagonist into the BLA before testing inhibits the expression of conditioned fear and anxiety-like behavior (Knoll et al, 2011; Smith et al, 2012). Thus, $\kappa$ opioid antagonism in the BLA may reduce the aversive quality of fear-associated cues. Conversely, systemic administration of $\kappa$-opioid receptor agonists produced anxietylike behaviors in the elevated-plus maze (Smith et al, 2012), possible by activating amygdala $\kappa$-opioid receptor (Bruchas et al, 2009). Given centrally, opioid receptor agonists have been shown to facilitate retention of passive avoidance when given before training (Kuzmin et al, 2006), although, electrophysiological in vitro experiments revealed that activation of $\kappa$-opioid receptors decreases synaptic transmission and inhibits long-term potentiation in the BLA of the mouse (Huge et al, 2009). At present, whether such effects would influence fear and extinction consolidation processes is unclear. However, the possibility that posttraining BLA injections of CIQ modulated $\kappa$-opioiddependent mechanisms that potentially impact fear and extinction processes cannot be excluded.

In the current study, we demonstrated that CIQ facilitates extinction of conditioned fear in mice. Specifically, when mice were given intra-BLA injections of CIQ at a dose of $10 \mu \mathrm{g} /$ side immediately after the extinction training session, they displayed less conditioned freezing than vehicleinjected mice. Because CIQ at this dose and higher $(30 \mu \mathrm{g})$ was found to increase conditioned freezing in mice that had received fear training, the enhancing effect of CIQ on extinction cannot be attributed to either CIQ-related neurotoxicity or to any drug effects (eg, anxiolytic-like actions) that may have been present at the time of testing. Although significant enhancing effects on extinction were obtained with a dose of $10 \mu \mathrm{g}$ CIQ/side, doses of 3 and $10 \mu \mathrm{g} /$ side led to only marginal, but nonsignifcant, increases in extinction. It is possible that at the higher $30 \mu \mathrm{g} / \mathrm{side}$ dose, CIQ can reach concentrations outside the BLA that starts to affect different inputs into the BLA, either by action on GluN2C/2D or one of the off-target receptors, which counteract the enhancing effect of CIQ. Future studies examining the effects of more selective GluN2C/2D agonists will be necessary to more fully elucidate the involvement of these NMDA receptors to memory consolidation mechanisms.

These results hold several important implications for learning. First, they show that positive allosteric modulation of NMDA receptors by small molecules can enhance learning in vivo. Second, they suggest the GluN2C subunit, a subunit about which little is known, has a central role in plasticity of certain brain circuits. More broadly, our findings raise the possibility that enhancement of learning involving specific brain regions can be selectively achieved through targeted allosteric potentiation of the receptors expressed in those regions. Hence, CIQ and other selective NMDA receptor allosteric modulators (Monaghan et al, 2012; Ogden and Traynelis, 2011) may be useful pharmacological tools for dissecting which receptors may underlie learning and memory. Moreover, potentiation of GluN2Ccontaining receptors may be an attractive strategy to treat a wide range of neurological diseases with learning and 
memory deficits, including post-traumatic stress disorder, anxiety disorders, and motor learning in stroke.

\section{FUNDING AND DISCLOSURE}

Stephen F Traynelis is a co-inventor on Emory-owned IP, and has an equity position in and is a paid consultant for a company developing NMDA receptor allosteric modulators (NeurOp Inc). Kevin K Ogden, Alpa Khatri, and Scott A Heldt have nothing to disclose. Scott A. Heldt received grant support from NIH (MH-086727), NARSAD, and a UTHSC base grant.

\section{REFERENCES}

Akazawa C, Shigemoto R, Bessho Y, Nakanishi S, Mizuno N (1994). Differential expression of five N-methyl-D-aspartate receptor subunit mRNAs in the cerebellum of developing and adult rats. J Comp Neurol 347: 150-160.

Assini FL, Duzzioni M, Takahashi RN (2009). Object location memory in mice: Pharmacological validation and further evidence of hippocampal CA1 participation. Behav Brain Res 204: 206-211.

Aura J, Riekkinen M, Riekkinen P Jr (1998). Tetrahydroaminoacridine and d-cycloserine stimulate acquisition of water maze spatial navigation in aged rats. Eur J Pharmacol 342: 15-20.

Bado P, Madeira C, Vargas-Lopes C, Moulin TC, WasilewskaSampaio AP, Maretti L et al (2011). Effects of low-dose D-serine on recognition and working memory in mice. Psychopharmacology 218: 461-470.

Baker JD, Azorlosa JL (1996). The NMDA antagonist MK-801 blocks the extinction of Pavlovian fear conditioning. Behav Neurosci 110: 618-620.

Bauer EP, Schafe GE, LeDoux JE (2002). NMDA receptors and L-type voltage-gated calcium channels contribute to long-term potentiation and different components of fear memory formation in the lateral amygdala. J Neurosci 22: 5239-5249.

Bombardi C (2011). Distribution of 5-HT2A receptor immunoreactivity in the rat amygdaloid complex and colocalization with $\gamma$-aminobutyric acid. Brain Res 1370: 112-128.

Bombardi C, Di Giovanni G (2013). Functional anatomy of 5-HT receptors in the amygdala and hippocampal complex: relevance to memory functions. Exp Brain Res doi:10.1007/s00221-0133512-6.

Bruchas MR, Land BB, Lemos JC, Chavkin C (2009). CRF1-R activation of the dynorphin/kappa opioid system in the mouse basolateral amygdala mediates anxiety-like behavior. PloS One 4: e8528.

Butelman ER, Yuferov V, Kreek MJ (2012). א-opioid receptor/ dynorphin system: genetic and pharmacotherapeutic implications for addiction. Trends Neurosci 35: 587-596.

Carr GV, Lucki I (2010). Comparison of the kappa-opioid receptor antagonist DIPPA in tests of anxiety-like behavior between Wistar Kyoto and Sprague Dawley rats. Psychopharmacology 210: 295-302.

Chen A, Hough CJ, Li H (2003). Serotonin type II receptor activation facilitates synaptic plasticity via n-methyl-d-aspartatemediated mechanism in the rat basolateral amygdala. Neuroscience 119: 53-63.

Clem RL, Huganir RL (2010). Calcium-permeable AMPA receptor dynamics mediate fear memory erasure. Science 330: 1108-1112.

Cryan JF, Sweeney FF (2011). The age of anxiety: role of animal models of anxiolytic action in drug discovery. Br J Pharmacol 164: 1129-1161.

Dalton GL, Wu DC, Wang YT, Floresco SB, Phillips AG (2012). NMDA GluN2A and GluN2B receptors play separate roles in the induction of LTP and LTD in the amygdala and in the acquisition and extinction of conditioned fear. Neuropharmacology 62: 797-806.

Dravid SM, Burger PB, Prakash A, Geballe MT, Yadav R, Le P et al (2010). Structural determinants of D-cycloserine efficacy at the NR1/NR2C NMDA receptors. J Neurosci 30: 2741-2754.

Eison AS, Mullins UL (1995). Regulation of central 5-HT2A receptors: a review of in vivo studies. Behav Brain Res 73: 177-181.

Fallon JH, Leslie FM (1986). Distribution of dynorphin and enkephalin peptides in the rat brain. J Comp Neurol 249: 293-336.

Falls WA, Miserendino MJ, Davis M (1992). Extinction of fearpotentiated startle: blockade by infusion of an NMDA antagonist into the amygdala. J Neurosci 12: 854-863.

Flood JF, Morley JE, Lanthorn TH (1992). Effect on memory processing by D-cycloserine, an agonist of the NMDA/glycine receptor. Eur J Pharmacol 221: 249-254.

Gladding CM, Raymond LA (2011). Mechanisms underlying NMDA receptor synaptic/extrasynaptic distribution and function. Mol Cell Neurosci 48: 308-320.

Graham BM, Langton JM, Richardson R (2011). Pharmacological enhancement of fear reduction: preclinical models. Br J Pharmacology 164: 1230-1247.

Gray JA, Shi Y, Usui H, During MJ, Sakimura K, Nicoll RA (2011). Distinct modes of AMPA receptor suppression at developing synapses by GluN2A and GluN2B: single-cell NMDA receptor subunit deletion in vivo. Neuron 71: 1085-1101.

Heldt SA, Ressler KJ (2006). Lesions of the habenula produce stress- and dopamine-dependent alterations in prepulse inhibition and locomotion. Brain Res 1073-1074: 229-239.

Hillman BG, Gupta SC, Stairs DJ, Buonanno A, Dravid SM (2011). Behavioral analysis of NR2C knockout mouse reveals deficit in acquisition of conditioned fear and working memory. Neurobiol Learn Mem 95: 404-414.

Hollmann M, Heinemann S (1994). Cloned glutamate receptors. Annu Rev Neurosci 17: 31-108.

Homberg JR (2012). Serotonergic modulation of conditioned fear. Scientifica 2012: 16.

Huge V, Rammes G, Beyer A, Zieglgänsberger W, Azad SC (2009). Activation of kappa opioid receptors decreases synaptic transmission and inhibits long-term potentiation in the basolateral amygdala of the mouse. Eur J Pain 13: 124-129.

Jamensky NT, Gianoulakis C (1997). Content of Dynorphins and k-Opioid Receptors in Distinct Brain Regions of C57BL/6 and DBA/2 Mice. Alcohol Clin Exp Research 21: 1455-1464.

Johansen JP, Cain CK, Ostroff LE, LeDoux JE (2011). Molecular mechanisms of fear learning and memory. Cell 147: 509-524.

Jones SV, Heldt SA, Davis M, Ressler KJ (2005). Olfactorymediated fear conditioning in mice: simultaneous measurements of fear-potentiated startle and freezing. Behav Neurosci 119: 329-335.

Kalisch R, Holt B, Petrovic P, De Martino B, Kloppel S, Buchel C et al (2009). The NMDA agonist D-cycloserine facilitates fear memory consolidation in humans. Cerebral cortex 19: 187-196.

Karavanova I, Vasudevan K, Cheng J, Buonanno A (2007). Novel regional and developmental NMDA receptor expression patterns uncovered in NR2C subunit-beta-galactosidase knock-in mice. Mol Cell Neurosci 34: 468-480.

King MV, Marsden CA, Fone KC (2008). A role for the 5-HT(1A), 5-HT4 and 5-HT6 receptors in learning and memory. Trends Pharmacol Sci 29: 482-492.

Knoll AT, Meloni EG, Thomas JB, Carroll FI, Carlezon WA (2007). Anxiolytic-like effects of $\kappa$-opioid receptor antagonists in models of unlearned and learned fear in rats. J Pharmacol Exp Ther 323: 838-845.

Knoll AT, Muschamp JW, Sillivan SE, Ferguson D, Dietz DM, Meloni EG et al (2011). Kappa opioid receptor signaling in the 
basolateral amygdala regulates conditioned fear and anxiety in rats. Biol Psychiatry 70: 425-433.

Korotkova T, Fuchs EC, Ponomarenko A, von Engelhardt J, Monyer H (2010). NMDA receptor ablation on parvalbuminpositive interneurons impairs hippocampal synchrony, spatial representations, and working memory. Neuron 68: 557-569.

Kuzmin A, Madjid N, Terenius L, Ogren SO, Bakalkin G (2006). Big dynorphin, a prodynorphin-derived peptide produces NMDA receptor-mediated effects on memory, anxiolytic-like and locomotor behavior in mice. Neuropsychopharmacology 31: 1928-1937.

Land C, Riccio DC (1999). d-Cycloserine: effects on long-term retention of a conditioned response and on memory for contextual attributes. Neurobiol Learn Mem 72: 158-168.

Ledgerwood L, Richardson R, Cranney J (2003). Effects of D-cycloserine on extinction of conditioned freezing. Behav Neurosci 117: 341-349.

Lee H, Kim JJ (1998). Amygdalar NMDA receptors are critical for new fear learning in previously fear-conditioned rats. J Neurosci 18: 8444-8454.

Li H, Penzo MA, Taniguchi H, Kopec CD, Huang ZJ, Li B (2013). Experience-dependent modification of a central amygdala fear circuit. Nat Neurosci 16: 332-339.

Lin C-H, Yeh S-H, Lu H-Y, Gean P-W (2003). The similarities and diversities of signal pathways leading to consolidation of conditioning and consolidation of extinction of fear memory. J Neurosci 23: 8310-8317.

Lindner MD, Hodges DB Jr, Hogan JB, Orie AF, Corsa JA, Barten DM et al (2003). An assessment of the effects of serotonin 6 (5HT6) receptor antagonists in rodent models of learning. J Pharmacol Exp Ther 307: 682-691.

Mansour A, Fox CA, Akil H, Watson SJ (1995). Opioid-receptor mRNA expression in the rat CNS: anatomical and functional implications. Trends Neurosci 18: 22-29.

McDonald AJ, Mascagni F (2007). Neuronal localization of 5-HT type $2 \mathrm{~A}$ receptor immunoreactivity in the rat basolateral amygdala. Neuroscience 146: 306-320.

McKernan MG, Shinnick-Gallagher P (1997). Fear conditioning induces a lasting potentiation of synaptic currents in vitro. Nature 390: 607-611.

McNally GP (2009). The roles of endogenous opioids in fear learning. Int J Comparative Psychol 22: 153-169.

Miserendino MJ, Sananes CB, Melia KR, Davis M (1990). Blocking of acquisition but not expression of conditioned fear-potentiated startle by NMDA antagonists in the amygdala. Nature 345: 716-718.

Mitchell ES, Neumaier JF (2005). 5-HT6 receptors: a novel target for cognitive enhancement. Pharmacol Ther 108: 320-333.

Mitchell ES, Neumaier JF (2008). 5-HT6 receptor antagonist reversal of emotional learning and prepulse inhibition deficits induced by apomorphine or scopolamine. Pharmacol, BiochemBehav 88: 291-298.

Monaghan DT, Irvine MW, Costa BM, Fang G, Jane DE (2012). Pharmacological modulation of NMDA receptor activity and the advent of negative and positive allosteric modulators. Neurochem Int 61: 581-592.

Monahan JB, Handelmann GE, Hood WF, Cordi AA (1989). D-cycloserine, a positive modulator of the N-methyl-D-aspartate receptor, enhances performance of learning tasks in rats. Pharmacol Biochem Behavi 34: 649-653.

Montezinho LP, Miller S, Plath N, Jensen NH, Karlsson JJ, Witten L et al (2010). The effects of acute treatment with escitalopram on the different stages of contextual fear conditioning are reversed by atomoxetine. Psychopharmacology 212: 131-143.

Monyer H, Burnashev N, Laurie DJ, Sakmann B, Seeburg PH (1994). Developmental and regional expression in the rat brain and functional properties of four NMDA receptors. Neuron 12: 529-540.
Mullasseril P, Hansen KB, Vance KM, Ogden KK, Yuan $\mathrm{H}$, Kurtkaya NL et al (2010). A subunit-selective potentiator of NR2Cand NR2D-containing NMDA receptors. Nat Commun 1: 90.

Myers KM, Carlezon WA Jr., Davis M (2011). Glutamate receptors in extinction and extinction-based therapies for psychiatric illness. Neuropsychopharmacology 36: 274-293.

Myers KM, Davis M (2007). Mechanisms of fear extinction. Mol Psychiatry 12: 120-150.

Ogden KK, Traynelis SF (2011). New advances in NMDA receptor pharmacology. Trends Pharmacol Sci 32: 726-733.

Paoletti P, Bellone C, Zhou Q (2013). NMDA receptor subunit diversity: impact on receptor properties, synaptic plasticity and disease. Nat Rev Neurosci 14: 383-400.

Paxinos G, Franklin K (2001). The Mouse Brain in Stereotaxic Coordinates. Academic Press: New York, NY, USA.

Pitkanen M, Sirvio J, MacDonald E, Ekonsalo T, Riekkinen P Sr. (1995). The effects of d-cycloserine, a partial agonist at the glycine binding site, on spatial learning and working memory in scopolamine-treated rats. J Neural Transm Park Dis Dement Sec 9: 133-144.

Rainnie DG (1999). Serotonergic Modulation of Neurotransmission in the Rat Basolateral Amygdala. J Neurophysiol 82: 69-85.

Research IoLA, Sciences CoL, Council NR (1996). Guide for the Care and Use of Laboratory Animals. The National Academies Press: Washington, D.C., USA.

Rodrigues SM, Schafe GE, LeDoux JE (2001). Intra-amygdala blockade of the NR2B subunit of the NMDA receptor disrupts the acquisition but not the expression of fear conditioning. J Neurosci 21: 6889-6896.

Rogan MT St, ubli UV, LeDoux JE (1997). Fear conditioning induces associative long-term potentiation in the amygdala. Nature 390: 604-607.

Santangelo Freel RM, Ogden KK, Strong KL, Khatri A, Chepiga KM, Jensen HS (2013). Synthesis and structure activity relationship of tetrahydroisoquinoline-based potentiators of GluN2C and GluN2D containing N-Methyl-D-Aspartate receptors. J Med Chem 56: 5351-5381.

Santini E, Muller RU, Quirk GJ (2001). Consolidation of extinction learning involves transfer from NMDA-independent to NMDAdependent memory. J Neurosci 21: 9009-9017.

Sanz-Clemente A, Nicoll RA, Roche KW (2013). Diversity in NMDA receptor composition: many regulators, many consequences. Neuroscientist 19: 62-75.

Schroeder BW, Shinnick-Gallagher P (2004). Fear memories induce a switch in stimulus response and signaling mechanisms for long-term potentiation in the lateral amygdala. Eur $J$ Neurosci 20: 549-556.

Schroeder BW, Shinnick-Gallagher P (2005). Fear learning induces persistent facilitation of amygdala synaptic transmission. Eur J Neurosci 22: 1775-1783.

Sheinin A, Shavit S, Benveniste M (2001). Subunit specificity and mechanism of action of NMDA partial agonist D-cycloserine. Neuropharmacology 41: 151-158.

Smith JS, Schindler AG, Martinelli E, Gustin RM, Bruchas MR, Chavkin C (2012). Stress-induced activation of the dynorphin/ kappa-opioid receptor system in the amygdala potentiates nicotine conditioned place preference. J Neurosci 32: 1488-1495.

Sobolevsky AI, Rosconi MP, Gouaux E (2009). X-ray structure, symmetry and mechanism of an AMPA-subtype glutamate receptor. Nature 462: 745-756.

Sokal DM, Giarola AS, Large CH (2005). Effects of GABAB, 5-HT1A, and 5-HT2 receptor stimulation on activation and inhibition of the rat lateral amygdala following medial geniculate nucleus stimulation in vivo. Brain Res 1031: 141-150.

Standaert DG, Testa CM, Young AB, Penney JB Jr (1994). Organization of N-methyl-D-aspartate glutamate receptor gene expression in the basal ganglia of the rat. J Comp Neurol 343: $1-16$. 
Stein C, Davidowa H, Albrecht D (2000). 5-HT(1A) receptormediated inhibition and 5-HT(2) as well as 5-HT(3) receptormediated excitation in different subdivisions of the rat amygdala. Synapse 38: 328-337.

Sunyer B, Patil S, Frischer C, Hoeger H, Lubec G (2008). Straindependent effects of cognitive enhancers in the mouse. Amino Acids 34: 485-495.

Suzuki A, Josselyn SA, Frankland PW, Masushige S, Silva AJ, Kida $S$ (2004). Memory reconsolidation and extinction have distinct temporal and biochemical signatures. $J$ Neurosci 24: 4787-4795.

Traynelis SF, Wollmuth LP, McBain CJ, Menniti FS, Vance KM, Ogden KK et al (2010). Glutamate receptor ion channels: structure, regulation, and function. Pharamacol Rev 62: 405-496.

Tsvetkov E, Carlezon WA, Benes FM, Kandel ER, Bolshakov VY (2002). Fear conditioning occludes LTP-induced presynaptic enhancement of synaptic transmission in the cortical pathway to the lateral amygdala. Neuron 34: 289-300.

Ulbrich MH, Isacoff EY (2008). Rules of engagement for NMDA receptor subunits. Proc Natl Acad Sci USA 105: 14163-14168.
Walker DL, Davis M (2008). Amygdala infusions of an NR2Bselective or an NR2A-preferring NMDA receptor antagonist differentially influence fear conditioning and expression in the fear-potentiated startle test. Learn Mem 15: 67-74.

Walker DL, Ressler KJ, Lu KT, Davis M (2002). Facilitation of conditioned fear extinction by systemic administration or intraamygdala infusions of D-cycloserine as assessed with fearpotentiated startle in rats. J Neurosci 22: 2343-2351.

Yang YL, Lu KT (2005). Facilitation of conditioned fear extinction by $\mathrm{d}$-cycloserine is mediated by mitogen-activated protein kinase and phosphatidylinositol 3-kinase cascades and requires de novo protein synthesis in basolateral nucleus of amygdala. Neuroscience 134: 247-260.

Zhang G, Asgeirsdottir HN, Cohen SJ, Munchow AH, Barrera MP, Stackman RW Jr. (2013). Stimulation of serotonin 2 A receptors facilitates consolidation and extinction of fear memory in C57BL/6J mice. Neuropharmacology 64: 403-413.

Zlomuzica A, De Souza Silva MA, Huston JP, Dere E (2007). NMDA receptor modulation by $\mathrm{D}$-cycloserine promotes episodic-like memory in mice. Psychopharmacology 193: 503-509. 